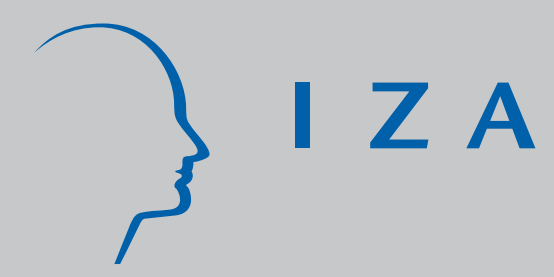

IZA DP No. 2162

Fertility and its Consequence on Family Labour Supply

J ungho Kim

Arnstein Aassve

J une 2006 


\title{
Fertility and its Consequence on Family Labour Supply
}

\author{
Jungho Kim \\ Vienna Institute of Demography \\ and IZA Bonn \\ Arnstein Aassve \\ ISER, University of Essex
}

Discussion Paper No. 2162

June 2006

\author{
IZA \\ P.O. Box 7240 \\ 53072 Bonn \\ Germany \\ Phone: +49-228-3894-0 \\ Fax: +49-228-3894-180 \\ Email: iza@iza.org
}

\begin{abstract}
Any opinions expressed here are those of the author(s) and not those of the institute. Research disseminated by IZA may include views on policy, but the institute itself takes no institutional policy positions.

The Institute for the Study of Labor (IZA) in Bonn is a local and virtual international research center and a place of communication between science, politics and business. IZA is an independent nonprofit company supported by Deutsche Post World Net. The center is associated with the University of Bonn and offers a stimulating research environment through its research networks, research support, and visitors and doctoral programs. IZA engages in (i) original and internationally competitive research in all fields of labor economics, (ii) development of policy concepts, and (iii) dissemination of research
\end{abstract} results and concepts to the interested public.

IZA Discussion Papers often represent preliminary work and are circulated to encourage discussion. Citation of such a paper should account for its provisional character. A revised version may be available directly from the author. 


\section{ABSTRACT}

\section{Fertility and its Consequence on Family Labour Supply}

While a large body of literature focuses on how fertility affects female labour market participation, there are relatively few studies that examine the effect of fertility on male labour market participation. Even if the burden of child care falls mainly on women, an exogenous increase in fertility is likely to change the optimal allocation of time, therefore, the labour supply decision of both female and male in a household. This paper analyses how an exogenous increase in fertility affects labour market participation of men and women in Indonesia - a country that has seen dramatic changes in the labour market over recent decades. The finding is that women reduce their working hours in response to the higher fecundity in both rural and urban areas in Indonesia. On the other hand, the higher fecundity leads to men's increasing their working hours only in rural areas. The higher degree of specialization in response to fertility in rural areas is driven mainly by the differences in the cost of childcare rather than the characteristics of occupation or household bargaining power.

JEL Classification: J13, J22, J24

Keywords: fertility, labour supply, division of labour, Indonesia

Corresponding author:

Jungho Kim

Vienna Institute of Demography

Prinz Eugen Strasse 8, 2nd floor

1040 Vienna

Austria

Email: jungho@alumni.brown.edu

\footnotetext{
* Authors would like to thank John Ermisch, Steve Pudney, Alexia Prskawetz and Fabrizia Mealli for their helpful discussions. The research has been supported by the Austrian Science Foundation (Contract No. P16903-605).
} 


\section{Introduction}

The majority of empirical studies concerning the consequences of fertility in terms of the labour market outcomes focus on female labour supply (see Browning 1992 for a survey). According to economic theory, although the burden of childcare tends to fall mainly on women, an increase in fertility is likely to change the optimal time allocation within the household, and therefore influence the labour supply decision - and their labour earnings - of both husband and wife (Becker 1985). Recently the literature has also focussed on male labour supply, but the few studies examining the impact of fertility on male as well as female labour supply are limited to developed countries (Angrist and Evans 1998, Millimet 2000, Lundberg and Rose 2000).

The objective of the paper is to empirically examine the effect of fertility on both men and women's labour supply using the data from Indonesia, a developing country with a large population and a huge geographical diversity. It further aims to investigate whether the consequences of fertility varies across rural and urban areas.

Given that the theoretical prediction on the effect of fertility on family labour supply requires a number of assumptions on the household preference and the characteristics of a production function of a child good, one empirical question is whether the degree of specialization between the husband and the wife would increase or decrease in response to an increase in fertility (Becker 1985, Angrist and Evans 1996 and Lundberg and Rose 2002). Recent empirical studies on fertility and family labour supply provide mixed results. Using the sex composition of the first two children as instrumental variables for fertility, Angrist and Evans (1998) found that in the U.S. fertility reduces female labour supply significantly but that there is no significant change in male labour supply. On the other hand, in their individual fixed-effect estimation, Lundberg and Rose (2002) found that the presence of children significantly increases male labour supply in the U.S. ${ }^{1}$ By estimating the

\footnotetext{
${ }^{1}$ The fixed-effect estimation leaves a potential endogeneity issue that the expectation on the events like a promotion
} 
allocation of time, the value of non-market time, job tenure, market wages, and fertility for married couple in the PSID sample, Millimet (2000) found that fertility reduces male and female labour supply and that it does not have a significant impact on male and female wages.

From the empirical perspective the main challenge lies in constructing an exogenous measure of fertility as a means to analyze the impact on labour supply. The most common approach is to employ instrumental variables estimation. Examples include Rosenzweig and Wolpin (1980) who use twins as instruments and Angrist and Evans (1998) who use the sex composition of the first two children as instruments estimating the effect of third birth on parents' labour supply. Neither approach is appealing in our case. The number of twins in our sample is not sufficient for sound statistical inference, and limiting the analysis to third births only restricts the sample substantially. Unfortunately there are few other valid instruments available. An alternative approach, however, involves estimation of a reproduction function taking into account endogenous contraceptive choice. This approach, first presented by Rosenzweig and Schultz (1985), provides an exogenous measure of fertility, or fecundity, which is used as a regressor in the labour supply functions for men and women. Since our data contains the detailed information on contraceptive choice, we build on the latter approach.

Our finding is that women reduce their working hours in response to the higher fecundity in both rural and urban areas in Indonesia. Whereas higher fecundity has no significant effect on the labour supply of men in urban areas, it does have a positive and significant effect on men's labour supply in rural areas. It is also found that using the number of children as a measure of fertility tends to exaggerate the consequence of fertility in both female and male labour supply, which is consistent with the finding by Rosenzweig and Schultz (1985). Further analysis suggests that the higher degree of specialization in response to an increase in fertility in rural areas is driven mainly may have an impact on fertility. 
by the regional differences in the cost of childcare rather than the characteristics of occupations or the bargaining power in Indonesia. The finding that men as well as women do respond to the trade-off between the cost of childcare and the value of their time provides evidence against the usual assumption that a husband's income is exogenous with respect to a wife's labour supply or the choice of childbearing even in the context of developing countries.

The paper is organized as follows. Section 2 provides a theoretical background. Section 3 describes the institutional setting and the data. Section 4 presents the empirical specification and the results. The final section presents conclusion.

\section{Theoretical Background}

Economic theory argues that fertility have two different effects on family labour supply. The first refers to the specialization effect derived from the fact that the responsibility of childcare tends to fall on women (Becker, 1985). It is argued that an increase in fertility will lead women to spend more energy and time on child care due to the increase in its effort intensity (per unit of time) in child care. In contrast, men are likely to spend more time and energy in market activities in response to an increase in fertility - in so far consumption goods and a child good are complementary.

Second, more children increases the value of parents' time as inputs in the production of a child good. In this case both the mother and the husband will reduce their labour supply in terms of time and energy, an effect Lundberg and Rose (2002) refer to as the home-intensity effect.

Both hypotheses predict that the female labour supply and earning will decrease in response to an increase in fertility. However, the male labour supply and earning may increase or decrease depending on which of the two effects (specialization and home-intensity) dominates the other.

By considering a dynamic model of fertility control and female labour supply, Rosenzweig and Schultz (1985) show that the effect of an exogenous increase in fertility on female labour 
market participation combines two opposing effects. One is the increase in the marginal utility of consumption good due to the higher fertility, which leads to an incentive to work more. The other is the increase in returns to spending time at home if a child good and leisure are complements in utility. When the husband's labour supply is considered in addition, the theoretical prediction requires a number of assumptions on the complementarity of husband and wife's leisure and the production function of child good (Angrist and Evans 1996). Given the theoretical development on family labour supply, we investigate whether an increase in fertility reinforces or lessens the specialization between the husband and wife.

One important implication of the model presented by Rosenzweig and Schultz (1985) is that using the number of actual births as a measure of fertility is likely to exaggerate the consequence of fertility on female labour supply. It is ambiguous whether this implication can be extended to the labour supply of each household member, but it will be relevant if the effects of fertility on husband and wife's labour supply have opposite signs.

\section{Indonesian Context and Data Description}

In most developing countries fertility decline comes along with increased household income, which in turn implies changing roles for women both in terms of work and fertility behaviour. Indonesia is perhaps the most striking example of this pattern. From being a very poor country with high fertility levels, Indonesia has over the last four decades experienced unprecedented economic growth together with a dramatic fertility decline. During the period from 1970 to 1995 GDP per capita increased by more than three times whereas total fertility rate fell by around 50 percent (Table 1). These trends reflect important structural changes of the Indonesian economy and society. One important development is the rapid urbanization. Whereas only 17 percent of the Indonesian 
Table 1: Total Fertility Rate, GDP per capita and Urbanization in Indonesia

\begin{tabular}{crrr}
\hline \hline Period & TFR & GDP per person & Percentage of Urban Population \\
\hline $1965-1970$ & 5.57 & 297.6 & 17.1 \\
$1970-1975$ & 5.20 & 384.3 & 19.3 \\
$1975-1980$ & 4.73 & 503.0 & 22.1 \\
$1980-1985$ & 4.11 & 601.7 & 26.1 \\
$1985-1990$ & 3.50 & 776.7 & 30.6 \\
$1990-1995$ & 3.00 & $1,048.70$ & 35.6 \\
\hline \hline
\end{tabular}

Notes: 1) Source of TFR: World Population Prospects: The 2000 Revision, Vol. I, United Nations Population Division (requoted from World Resources Institute)

2) Source of GDP per capita: World Development Indicators 2004, The World Bank.

3) Source of Urban population: World Urbanization Prospects: The 2003 Revision. United Nations Population Division (requoted from World Resources Institute).

4) GDP per capita is in constant 1995 US dollars, and indicates the value in the last year of each period.

5) Percentage of urban population also indicates the values in the last year of each period.

population lived in urban areas in 1970, the proportion was more than doubled by 1995 (Table 1). This has lead to a significant reduction of households working in traditional and labour intensive farming communities thereby changing women's role in the labour market. These structural changes over time did not take place universally across regions. According to the 1990 Indonesian Population Census, only a tiny fraction of the work force in Jakarta was engaged in agriculture, whereas the proportion was 45 percent in the province of West Java, and as high as 70 percent in the province of Lampung in Sumatra island just across Sunda Strait from West Java. As a result there is a huge geographical diversity in terms of fertility and labour market behaviour. This underpins the importance of understanding household behaviour in rural as well as urban areas. Consequently, we control for village fixed effects, but analyse directly urban and rural differences, highlighting the importance of the structural characteristics in the local economy.

We use data from the Indonesian Family Life Survey (IFLS), which was collected in 1993, 1997, and 2000. The IFLS has extensive questionnaires concerning fertility, labour market participation, migration and health, to mention a few. The first wave consists of 7,224 households, whereas split- 
Table 2: Summary Statistics $(N=3,287)$

\begin{tabular}{lrrrr}
\hline \hline Variable & Mean & Std. Dev. & Min. & Max \\
\hline & & & & \\
Respondents' Characteristics & 34.48 & 6.89 & 17.00 & 51.00 \\
\hline Age & 4.95 & 3.97 & 0.00 & 18.00 \\
Completed years of schooling & 0.53 & 0.50 & 0.00 & 1.00 \\
Having a job & 16.42 & 21.39 & 0.00 & 94.00 \\
Number of hours of working per week & 1977.09 & 7.28 & 1955 & 1988 \\
Year of marriage & 0.87 & 0.34 & 0.00 & 1.00 \\
Muslim & 3.32 & 2.39 & 0.00 & 18.00 \\
Number of live births prior to 1989 & 0.57 & 0.72 & 0.00 & 5.00 \\
Number of births between 1989 and 1992 & 0.02 & 0.03 & 0.00 & 0.33 \\
Conception rate & 52.14 & 9.16 & 6.00 & 62.00 \\
Total months at risk of pregnancy & & & & \\
& & & & \\
Proportion of months using: & 0.13 & 0.29 & 0.00 & 1.00 \\
\hline Pills & 0.13 & 0.31 & 0.00 & 1.00 \\
IUD & 0.13 & 0.27 & 0.00 & 1.00 \\
Injection/Impant/Diaphragm/Condom & 0.04 & 0.19 & 0.00 & 1.00 \\
Female/Male Sterilization & 0.03 & 0.16 & 0.00 & 1.00 \\
Ineffective Methods & & & & \\
Husband's Characteristics & & & & \\
\hline Husband's age & & & & \\
Husband's completed years of schooling & 60.27 & 8.71 & 18.00 & 81.00 \\
Husband having a job & 1.00 & 0.33 & 0.00 & 18.00 \\
Husband's number of hours of working per week & 37.85 & 18.33 & 0.00 & 1.00 \\
\hline \hline
\end{tabular}

Notes: 1) The data used are the 1993 Indonesian Family Life Survey.

2) Ineffective methods of contraception include rhythm methods, withdrawal, traditional herbs and traditional massage. 
off households (as well as original households) were re-interviewed in the subsequent surveys. The response rates for the second and third wave are over 90 percent. Crucially for this study, the first wave (IFLS1) contains detailed information on contraceptive behaviour. Consequently our analysis focuses on women and households in the first wave only. ${ }^{2}$ There are a total of 4,890 women for whom detailed information on birth history, marriage and contraception is available in the IFLS1. The analysis is restricted to women married for at least five years and whose spouse is identified in the IFLS sample. The final sample includes 3,287 women with no missing values for the relevant variables.

The summary statistics are presented in Table 2. On average, women are 34.5 years old, and have five years of completed schooling. Half of the women have a job in 1993, and the mean working hours is 16.4 hours per week. They had 3.3 children by 1989, and had 0.6 births between 1989 and 1992. Their husbands are on average six years older, and have one more year of schooling. The husbands' average hours of work are 37.9 hours per week. The average number of months when a woman is exposed to the risk of pregnancy is 52 months out of five-year period prior to the survey, and the average monthly conception rate is two percent. The usage of contraceptives varies from 3 percent for ineffective methods to 13 percent for pills or IUD.

\section{Empirical Analysis}

The empirical strategy is implemented in two stages. First, we estimate the reproduction function as a means to derive the natural variation of fertility (i.e. fecundity), which in turn is taken as an exogenous measure of fertility. Second, we estimate a series of regressions where we analyze the effect of fertility on female and male labour supply - estimated both separately and jointly, and on female and male earnings.

\footnotetext{
${ }^{2}$ Information on contraceptive behaviour is also collected in the third wave (2000), so the study can be expanded accordingly.
} 


\subsection{Specification of the Reproduction Function}

The key purpose of estimating the reproduction function is to identify the part of realized fertility not explained by contraceptive efforts and women's observable biological characteristics, which in turn is considered as the variation of natural fertility. We refer to this measure as fecundity and we take the following linear approximation for the reproduction function.

$$
N_{j, t}=\mu_{j}+\beta Z_{j, t}+\gamma X_{j, t}+\varepsilon_{j, t}
$$

where $N_{j, t}$ is the conception rate of a woman $j$ at period $t, \mu_{j}$ is a woman-specific fecundity, $Z_{j, t}$ is a vector of variables measuring couples' contraceptive behaviour, and $X_{j, t}$ is a vector of observable biological characteristics of the woman. Thus the realized conception rate is considered as a function of fecundity, contraceptive efforts and observable biological characteristics of women, which includes age and the number of children prior to period $t$. The IFLS provides a monthly contraceptive calendar over the five years prior to the survey, from which we derive the conception rate and the measure of contraception. This forms the dependent variable in the reproduction function, which is essentially measured by the number of conceptions per month at risk of pregnancy over the five years prior to the time of survey. On average, the conception rate is 2 percent, and the number of months at risk of pregnancy is 52 months. The proportion of months using contraceptive methods ranges from 3 percent to 13 percent. The estimation of Equation 1 is problematic for two reasons. First, the choice of contraception and the methods will be correlated with fecundity if women are at least partly aware of their fecundity through their past experience. Second, womanspecific fecundity, $\mathrm{m}$ will be correlated with past realized births. We deal with this endogeneity issue by instrumenting the choice of contraceptives and the number of children ever born prior to 1989 , with a set of variables that affects the demand for children. The contraceptive methods include pills, IUD, injection, implant, diaphragm/condom, female/male sterilization, and other 
less effective methods such as withdrawal, rhythm, and so on. The instruments include schooling, spouse's schooling, being Muslim, number of women of age above nine in a household, an index for living with parents, an index for living with parent-in-laws and community dummy variables. Availability of family planning, and therefore use of contraceptives, varies at village levels. In the subsequent empirical analysis village fixed effects are removed.

Table 3 presents the results from the estimation of the reproduction function. The Ordinary Least Squares (OLS) estimation in column (1) suggests that the use of various contraceptives is negatively correlated with conception rate. The conception rate is lower for older women, and the effect of age seems to be linear. The Instrumental Variables (IV) estimations show a different picture. In general the coefficients associated with contraceptive methods become larger in magnitude suggesting that more fecund women tend to use more contraceptives, which is as expected. The estimates also show that the effectiveness of pills in the OLS is underestimated by 40 percent. Any selection related to the choice of IUD, injection, implant, diaphragm or condom seems to be small because their effectiveness do not change much in the IV estimation. The effectiveness of sterilization is more than 30 percent underestimated in the OLS estimation, and the IV estimates shows that methods termed ineffective are indeed ineffective. The Hausman test rejects the hypothesis that there is no systematic difference between the estimates from the OLS and the IV estimation at one percent level suggesting the significance of the correlation between fecundity and contraception. The first stage estimation is reported in Table 7 in Appendix A. ${ }^{3}$

Given the estimation of Equation 1 we calculate the permanent measure of natural fertility by taking the average of the difference between the actual fertility and the fertility predicted by the

\footnotetext{
${ }^{3}$ In order to take into account the fact that the mean monthly conception rate is very low, we also ran a Tobit model as in Rosenzweig and Schultz (1985). That is, a conception takes place only when a latent variable is greater than zero. The estimation results are essentially the same as those in the OLS and IV.
} 
Table 3: Determinants of Conception Rates

\begin{tabular}{lcc}
\hline \hline & $(1)$ & $(2)$ \\
& OLS & IV \\
\hline \multirow{2}{*}{ Pills } & -0.0256 & -0.0442 \\
& $(15.99)$ & $(10.50)$ \\
IUD & -0.0227 & -0.0219 \\
& $(14.49)$ & $(6.27)$ \\
Injection, Implant, Diaphragm, Condom & -0.0234 & -0.0236 \\
& $(13.86)$ & $(4.72)$ \\
Female/Male Sterilization & -0.0187 & -0.0280 \\
& $(7.53)$ & $(3.88)$ \\
Ineffective Methods & -0.0164 & -0.0019 \\
& $(5.79)$ & $(0.23)$ \\
Number of live births up to 1988 & 0.0000 & 0.0019 \\
& $(0.20)$ & $(4.04)$ \\
Age in 1988 & -0.0020 & -0.0021 \\
& $(5.17)$ & $(4.90)$ \\
Age in 1988 sq. & 0.0000 & 0.0000 \\
& $(0.89)$ & $(0.19)$ \\
Constant & 0.0822 & 0.0871 \\
& $(15.99)$ & $(15.44)$ \\
No. of Observation & 4,548 & 4,548 \\
R-squared & 0.26 & 0.21 \\
& & \\
\hline \hline
\end{tabular}

Notes: The dependent variable is the conception rate defined as the number of months of conception out of the total months at risk of pregnancy. Absolute value of asymptotic $t$-ratios are in parentheses. The data used are the 1993 Indonesian Family Life Survey. The instruments in column (2) include schooling, spouse's schooling, being Muslim, community dummies. 
reproduction function as follows.

$$
\mu_{j}=\frac{\sum_{t=1}^{t=T} N_{j, t}-\hat{N}_{j, t}}{T}
$$

The random error in each period is calculated as the difference between residual in each period and the measure of individual specific fecundity $\left(\varepsilon_{j, t}=N_{j, t}-\widehat{N_{j, t}}-\mu_{j}\right)$. We divide the 60 -month periods into two periods in order to separate the permanent and temporary component of fecundity.

\subsection{Fertility and Family Labour Supply}

We consider a household in which two adults make a decision on their labour supply. We do not attempt to distinguish between a unitary model and a collective model in the decision making process. Rather, our primary interest is to look at how the allocation of time of two adults changes in response to the natural variation of fertility. In contrast to Rosensweig and Schultz (1985), we estimate also the effect of fecundity on husband's labour supply.

We analyse the impact of fertility or fecundity on the number of hours worked by considering the usual conditional demand function of female labour supply (Blundell and Macurdy 1999):

$$
H_{F}^{*}=h_{F}\left(W_{M}, W_{F}, X, \mu, \varepsilon\right)
$$

which states that the hours of work for a woman, $H_{F}^{*}$, is a function of the male and female wages ( $W_{M}$ and $\left.W_{F}\right)$, household characteristics $(X)$, the permanent component of fecundity $(\mu)$, and the random component of fecundity $(\varepsilon) .{ }^{4}$ Since the information on the relevant wage is not available, we include directly the quadratic form of age and schooling of both husband and wife as the determinants of wage in the estimation below. The following Tobit model is considered where a

\footnotetext{
${ }^{4}$ In the empirical analysis, we consider the recent random component of fecundity, that is, in the second half of the previous 60 -month period $\left(\varepsilon=\varepsilon_{j, 2}=N_{j, 2}-\widehat{N_{j, 2}}-\mu_{j}\right)$.
} 
woman's hours of working is observed to be zero if the latent demand is below zero.

$$
H_{F}=\left\{\begin{array}{l}
H_{F}^{*} \quad \text { if } \quad H_{F}^{*}>0 \\
0 \quad \text { if } \quad H_{F}^{*} \leq 0
\end{array}\right.
$$

A linear specification for the conditional demand function for labour supply is taken as follows. ${ }^{5}$

$$
H_{F}^{*}=\beta_{0} W_{M}+\beta_{1} W_{F}+\beta_{2} X+\beta_{3} \mu+\beta_{4} \varepsilon+\epsilon_{F}
$$

As a means to analyse the effect of fecundity on female labour supply in rural and urban areas respectively, we estimate the following specification:

$$
H_{F}^{*}=\beta_{0} W_{M}+\beta_{1} W_{F}+\beta_{2} X+\beta_{5} \mu U R B A N+\beta_{6} \varepsilon U R B A N+\beta_{7} \mu R U R A L+\beta_{8} \varepsilon R U R A L+\epsilon_{F}
$$

where $U R B A N$ and $R U R A L$ are dichotomous variables indicating whether the household resides in either an urban area or a rural ones.

An alternative specification is a Probit model of the female labour market participation. Since the Probit model delivers qualitatively the same results as those from the Tobit model presented below, the results are presented in Appendix B. It turns out that controlling for the variations in prices or in infrastructure at the community level is important in the estimation, which is also illustrated in Appendix B. Given the huge geographical diversity of Indonesian economy and the importance of community level differences, we focus on the fixed-effects estimation in the main empirical analysis of the paper.

The results from the Tobit estimation are presented in Table 4. The dependent variable is the $\log$ of the weekly hours of work for women. The effect of a woman's age suggests that female labour supply peaks at the age of around 41. The marginal effect of own education also exhibits a nonlinear pattern. For women with less than four years of schooling, more education has a negative

\footnotetext{
${ }^{5}$ Pagan (1984) addresses the issue of regressions with generated regressors. His findings are not directly applicable to our econometric model, since the first stage estimation (reproduction function) involves a larger sample than the second stage estimation (labour supply).
} 
Table 4: Effects of Fecundity on Female Labour Supply (Tobit Model)

\begin{tabular}{|c|c|c|c|c|}
\hline Community fixed effects & $\begin{array}{c}(1) \\
\text { YES }\end{array}$ & $\begin{array}{l}(2) \\
\text { YES }\end{array}$ & $\begin{array}{l}(3) \\
\text { YES }\end{array}$ & $\begin{array}{c}(4) \\
\text { YES }\end{array}$ \\
\hline Dependent variable: $\log$ of female weekly hours of working & n 1993 & & & \\
\hline Wife's age & $\begin{array}{l}0.3226 \\
(4.18)\end{array}$ & $\begin{array}{l}0.3218 \\
(4.17)\end{array}$ & $\begin{array}{l}0.3092 \\
(4.02)\end{array}$ & $\begin{array}{l}0.3089 \\
(4.01)\end{array}$ \\
\hline Wife's age squared & $\begin{array}{c}-0.0039 \\
(3.67)\end{array}$ & $\begin{array}{c}-0.0039 \\
(3.67)\end{array}$ & $\begin{array}{c}-0.0038 \\
(3.63)\end{array}$ & $\begin{array}{c}-0.0038 \\
(3.62)\end{array}$ \\
\hline Wife's schooling & $\begin{array}{c}-0.1684 \\
(4.04)\end{array}$ & $\begin{array}{c}-0.1680 \\
(4.03)\end{array}$ & $\begin{array}{c}-0.1771 \\
(4.24)\end{array}$ & $\begin{array}{c}-0.1770 \\
(4.24)\end{array}$ \\
\hline Wife's schooling squared & $\begin{array}{l}0.0204 \\
(6.35)\end{array}$ & $\begin{array}{l}0.0204 \\
(6.35)\end{array}$ & $\begin{array}{l}0.0210 \\
(6.50)\end{array}$ & $\begin{array}{l}0.0210 \\
(6.49)\end{array}$ \\
\hline Husband's age & $\begin{array}{c}-0.0133 \\
(0.26)\end{array}$ & $\begin{array}{c}-0.0100 \\
(0.20)\end{array}$ & $\begin{array}{c}-0.0141 \\
(0.27)\end{array}$ & $\begin{array}{c}-0.0142 \\
(0.28)\end{array}$ \\
\hline Husband's age squared & $\begin{array}{l}0.0002 \\
(0.38)\end{array}$ & $\begin{array}{l}0.0002 \\
(0.32)\end{array}$ & $\begin{array}{l}0.0002 \\
(0.39)\end{array}$ & $\begin{array}{l}0.0002 \\
(0.39)\end{array}$ \\
\hline Husband's schooling & $\begin{array}{l}0.0613 \\
(1.47)\end{array}$ & $\begin{array}{l}0.0610 \\
(1.47)\end{array}$ & $\begin{array}{l}0.0600 \\
(1.45)\end{array}$ & $\begin{array}{l}0.0600 \\
(1.45)\end{array}$ \\
\hline Husband's schooling squared & $\begin{array}{c}-0.0079 \\
(2.71)\end{array}$ & $\begin{array}{c}-0.0079 \\
(2.72)\end{array}$ & $\begin{array}{c}-0.0079 \\
(2.69)\end{array}$ & $\begin{array}{c}-0.0079 \\
(2.69)\end{array}$ \\
\hline Muslim & $\begin{array}{c}-0.3323 \\
(1.42)\end{array}$ & $\begin{array}{c}-0.3371 \\
(1.44)\end{array}$ & $\begin{array}{c}-0.3297 \\
(1.41)\end{array}$ & $\begin{array}{c}-0.3291 \\
(1.41)\end{array}$ \\
\hline$\widehat{\mu}$ (permanent component of fecundity) & $\begin{array}{c}-0.0693 \\
(1.79)\end{array}$ & & & \\
\hline$\widehat{\varepsilon}$ (random component of fecundity) & $\begin{array}{l}0.0422 \\
(0.98)\end{array}$ & & & \\
\hline No. of live births between 1989 and 1992 & & & $\begin{array}{c}-0.2202 \\
(2.84)\end{array}$ & \\
\hline No. of live births prior to 1989 & & & $\begin{array}{c}-0.0050 \\
(0.18)\end{array}$ & \\
\hline$\widehat{\mu} * \operatorname{URBAN}\left(\beta_{5}\right)$ & & $\begin{array}{c}-0.0412 \\
(0.62)\end{array}$ & & \\
\hline$\widehat{\varepsilon} * \operatorname{URBAN}\left(\beta_{6}\right)$ & & $\begin{array}{l}0.0962 \\
(1.30)\end{array}$ & & \\
\hline$\widehat{\mu} * \operatorname{RURAL}\left(\beta_{7}\right)$ & & $\begin{array}{c}-0.0872 \\
(1.86)\end{array}$ & & \\
\hline$\widehat{\varepsilon} * \operatorname{RURAL}\left(\beta_{8}\right)$ & & $\begin{array}{l}0.0125 \\
(0.24)\end{array}$ & & \\
\hline No. of live births between 1989 and $1992 *$ URBAN $\left(\beta_{9}\right)$ & & & & $\begin{array}{c}-0.2304 \\
(1.93)\end{array}$ \\
\hline No. of live births prior to $1989 *$ URBAN $\left(\beta_{10}\right)$ & & & & $\begin{array}{c}-0.0091 \\
(0.24)\end{array}$ \\
\hline No. of live births between 1989 and $1992 *$ RURAL $\left(\beta_{11}\right)$ & & & & $\begin{array}{c}-0.2133 \\
(2.17)\end{array}$ \\
\hline No. of live births prior to $1989 *$ RURAL $\left(\beta_{12}\right)$ & & & & $\begin{array}{c}-0.0021 \\
(0.06)\end{array}$ \\
\hline Constant & $\begin{array}{c}-6.2374 \\
(3.99)\end{array}$ & $\begin{array}{c}-6.2251 \\
(3.99)\end{array}$ & $\begin{array}{c}-5.5607 \\
(3.52)\end{array}$ & $\begin{array}{c}-5.5721 \\
(3.52)\end{array}$ \\
\hline No. of Observations & 3,287 & 3,287 & 3,287 & 3,287 \\
\hline $\begin{array}{l}\text { No. of Communities } \\
p \text {-values for }\end{array}$ & 311 & 311 & 311 & 311 \\
\hline$H_{0}: \beta_{5}=\beta_{7}$ & & 0.571 & & \\
\hline$H_{0}: \beta_{6}=\beta_{8}$ & & 0.347 & & \\
\hline$H_{0}: \beta_{9}=\beta_{11}$ & & & & 0.910 \\
\hline$H_{0}: \beta_{10}=\beta_{12}$ & & & & 0.875 \\
\hline
\end{tabular}

Notes: Absolute value of asymptotic $t$-ratios are in parentheses. The data used are the 1993 Indonesian Family Life Survey. All columns include community fixed effects. Measure of Fecundity is adjusted so that one unit of fecundity is equivalent to an increase by one expected birth over 5 years. 
impact on working hours, while for women with more than four years of schooling higher education implies larger hours of work. This result is consistent with the hypothesis that in developing countries, at low levels of schooling, the return to women's education in home production is greater than the market return (Lam and Duryea 1999). Thus, if highly educated women are better at raising children than less educated counterparts, more education may not necessarily lead to an increase in women's working hours. The impact of husband's schooling on wife's labour supply is also highly non-linear, indicating that for more than four years of husband's schooling, the wife's labour supply decreases, which can be seen as an income effect. Note that the measure of fecundity is expressed in terms of monthly probability of conception. ${ }^{6}$ An increase of permanent component of fecundity by one unit decreases female labour supply by 7 percent, or 1.1 hour per week. Column (3) indicates that experiencing a birth over the previous five years is associated with 22 percent decrease of female working hours, or 3.6 hours per week. It is clear that using the number of births as a measure of fertility exaggerates the consequence of fertility in terms of female labour supply, which is consistent with the finding by Rosenzweig and Schultz (1985). We fail to reject the hypothesis that the coefficients on the measures of fertility are the same for rural and urban areas based on the p-values presented at the bottom of columns (2) and (4). Hence, the permanent component of fecundity has a significant and negative impact on female labour supply in both rural and urban areas in Indonesia.

Next we analyse the effect of fertility on husband's labour supply. As in the case for women, the following conditional demand function for labour supply is considered:

$$
H_{M}^{*}=h_{M}\left(W_{M}, W_{F}, X, \mu, \varepsilon\right)
$$

\footnotetext{
${ }^{6}$ Since an increase in fecundity by $1 / 51$ leads to an increase of approximately one expected birth over 51 -month period (comprising five-year period with nine months of pregnancy), we multiply the fecundity measures by 51 in all the specifications in the paper so that one unit of fecundity is comparable to an increase of one birth between 1989 and 1992 .
} 
where $H_{M}^{*}$ indicates the husband's hours of work. Since men are assumed to work full time, a linear regression model for the conditional demand function is taken as follows:

$$
H_{M}^{*}=\gamma_{0} W_{M}+\gamma_{1} W_{F}+\gamma_{2} X+\gamma_{3} \mu+\gamma_{4} \varepsilon+\epsilon_{M}
$$

The alternative model of Equation 8 examines whether the effect of fecundity on male labour supply is different for rural and urban areas (Equation 9).

$$
H_{M}^{*}=\gamma_{1} W_{M}+\gamma_{2} W_{F}+\gamma_{3} X+\gamma_{5} \mu U R B A N+\gamma_{6} \varepsilon U R B A N+\gamma_{7} \mu R U R A L+\gamma_{8} \varepsilon R U R A L+\epsilon_{M}
$$

Table 5 presents the results. The dependent variable is the log of husband's weekly hours of work. In column (1), the coefficients on husband's age and its square term indicate that the male labour supply exhibits a hump shape with respect to own age, peaking at 40 years of age. The quadratic form of own education also indicates a non-linear effect. For less than six years of schooling, there is a positive effect of education on hours worked, while for more than six years of schooling, higher education implies reduced hours worked. Since education is a proxy for wage levels, this result indicates a standard upward-sloping labour supply curve that is bent backward for high wage levels. However, the fact that the sample mean for male schooling is six years suggests that the return to higher education is not large in Indonesia. Women's age and education do not seem to have any significant impact on male labour supply. The effect of the permanent component of fecundity is positive, but is imprecisely estimated, whereas the effect of having a birth between 1989 and 1992 (reported in column (3)) is positive and larger than that in column (1), but again imprecisely estimated.

Moving on to the specification which separates out rural and urban differentials (i.e. column (2) in Table 5) we see that the effect of the fecundity (m) is positive and significant in rural area but insignificant in urban areas. The hypothesis test is marginally in favour of the significantly different effects of fecundity on male labour supply for rural and urban areas (p-value is 5.5 percent). The 


\section{Table 5: Effects of Fecundity on Male Labour Supply (Regression Model)}

\begin{tabular}{|c|c|c|c|c|}
\hline Community fixed effects & $\begin{array}{c}(1) \\
\text { YES }\end{array}$ & $\begin{array}{l}(2) \\
\text { YES }\end{array}$ & $\begin{array}{c}(3) \\
\text { YES }\end{array}$ & $\begin{array}{c}(4) \\
\text { YES }\end{array}$ \\
\hline \multicolumn{5}{|c|}{ Dependent variable: log of male weekly hours of working in 1993} \\
\hline Wife's age & $\begin{array}{c}-0.0317 \\
(1.69)\end{array}$ & $\begin{array}{c}-0.0317 \\
(1.69)\end{array}$ & $\begin{array}{c}-0.0292 \\
(1.56)\end{array}$ & $\begin{array}{c}-0.0285 \\
(1.52)\end{array}$ \\
\hline Wife's age squared & $\begin{array}{l}0.0004 \\
(1.40)\end{array}$ & $\begin{array}{l}0.0004 \\
(1.43)\end{array}$ & $\begin{array}{c}0.0004 \\
(1.38)\end{array}$ & $\begin{array}{c}0.0003 \\
(1.34)\end{array}$ \\
\hline Wife's schooling & $\begin{array}{c}-0.0003 \\
(0.03)\end{array}$ & $\begin{array}{l}0.0003 \\
(0.03)\end{array}$ & $\begin{array}{l}0.0013 \\
(0.13)\end{array}$ & $\begin{array}{l}0.0014 \\
(0.14)\end{array}$ \\
\hline Wife's schooling squared & $\begin{array}{c}-0.0002 \\
(0.24)\end{array}$ & $\begin{array}{c}-0.0002 \\
(0.29)\end{array}$ & $\begin{array}{c}-0.0003 \\
(0.36)\end{array}$ & $\begin{array}{c}-0.0003 \\
(0.35)\end{array}$ \\
\hline Husband's age & $\begin{array}{l}0.0318 \\
(2.52)\end{array}$ & $\begin{array}{l}0.0315 \\
(2.49)\end{array}$ & $\begin{array}{l}0.0317 \\
(2.49)\end{array}$ & $\begin{array}{l}0.0314 \\
(2.46)\end{array}$ \\
\hline Husband's age squared & $\begin{array}{c}-0.0004 \\
(2.63)\end{array}$ & $\begin{array}{c}-0.0004 \\
(2.62)\end{array}$ & $\begin{aligned}= & -0.0004 \\
& (2.60)\end{aligned}$ & $\begin{array}{c}-0.0004 \\
(2.58)\end{array}$ \\
\hline Husband's schooling & $\begin{array}{l}0.0193 \\
(1.88)\end{array}$ & $\begin{array}{l}0.0190 \\
(1.86)\end{array}$ & $\begin{array}{l}0.0192 \\
(1.88)\end{array}$ & $\begin{array}{l}0.0191 \\
(1.86)\end{array}$ \\
\hline Husband's schooling squared & $\begin{array}{c}-0.0015 \\
(2.15)\end{array}$ & $\begin{array}{c}-0.0015 \\
(2.10)\end{array}$ & $\begin{array}{l}-0.0015 \\
(2.16)\end{array}$ & $\begin{array}{c}-0.0015 \\
(2.15)\end{array}$ \\
\hline Muslim & $\begin{array}{l}-0.0622 \\
(1.06)\end{array}$ & $\begin{array}{l}-0.0638 \\
(1.09)\end{array}$ & $\begin{array}{l}-0.0631 \\
(1.08)\end{array}$ & $\begin{array}{c}-0.0640 \\
(1.09)\end{array}$ \\
\hline$\widehat{\mu}$ (permanent component of fecundity) & $\begin{array}{l}0.0125 \\
(1.39)\end{array}$ & & & \\
\hline$\widehat{\varepsilon}$ (random component of fecundity) & $\begin{array}{l}-0.0175 \\
(1.76)\end{array}$ & & & \\
\hline No. of live births between 1989 and 1992 & & & $\begin{array}{l}0.0354 \\
(1.87)\end{array}$ & \\
\hline No. of live births prior to 1989 & & & $\begin{array}{l}0.0006 \\
(0.09)\end{array}$ & \\
\hline$\widehat{\mu} * \operatorname{URBAN}\left(\gamma_{5}\right)$ & & $\begin{array}{c}-0.0122 \\
(0.77)\end{array}$ & & \\
\hline$\widehat{\varepsilon}^{*} \operatorname{URBAN}\left(\gamma_{6}\right)$ & & $\begin{array}{c}-0.0071 \\
(0.40)\end{array}$ & & \\
\hline$\widehat{\mu} * \operatorname{RURAL}\left(\gamma_{7}\right)$ & & $\begin{array}{l}0.0242 \\
(2.24)\end{array}$ & & \\
\hline$\widehat{\varepsilon}^{*} \operatorname{RURAL}\left(\gamma_{8}\right)$ & & $\begin{array}{l}-0.0203 \\
(1.72)\end{array}$ & & \\
\hline No. of live births between 1989 and $1992 *$ URBAN $\left(\gamma_{9}\right)$ & & & & $\begin{array}{l}-0.0006 \\
(0.02)\end{array}$ \\
\hline No. of live births prior to $1989 *$ URBAN $\left(\gamma_{10}\right)$ & & & & $\begin{array}{c}-0.0005 \\
(0.06)\end{array}$ \\
\hline No. of live births between 1989 and $1992 *$ RURAL $\left(\gamma_{11}\right)$ & & & & $\begin{array}{l}0.0620 \\
(2.52)\end{array}$ \\
\hline No. of live births prior to $1989 *$ RURAL $\left(\gamma_{12}\right)$ & & & & $\begin{array}{l}0.0019 \\
(0.22)\end{array}$ \\
\hline Constant & $\begin{array}{l}7.4327 \\
(23.80)\end{array}$ & $\begin{array}{l}7.4325 \\
(23.79)\end{array}$ & $\begin{array}{l}7.3190 \\
(23.01)\end{array}$ & $\begin{array}{l}7.3124 \\
(22.96)\end{array}$ \\
\hline No. of Observations & 3,287 & 3,287 & 3,287 & 3,287 \\
\hline No. of Communities & 311 & 311 & 311 & 311 \\
\hline $\begin{array}{l}\mathrm{R} \text { squared } \\
p \text {-values for }\end{array}$ & 0.01 & 0.01 & 0.01 & 0.01 \\
\hline $\begin{array}{l}H_{0}: \gamma_{5}=\gamma_{7} \\
H_{0}: \gamma_{6}=\gamma_{8}\end{array}$ & & $\begin{array}{l}0.058 \\
0.529\end{array}$ & & \\
\hline$H_{0}: \gamma_{9}=\gamma_{11}$ & & & & 0.090 \\
\hline$H_{0}: \gamma_{10}=\gamma_{12}$ & & & & 0.824 \\
\hline
\end{tabular}

Notes: Absolute value of asymptotic $t$-ratios are in parentheses. The data used are the 1993 Indonesian Family Life Survey. All columns include community fixed effects. Measure of Fecundity is adjusted so that one unit of fecundity is equivalent to an increase by one expected birth over 5 years. Other regressors include the age, age squared, schooling and schooling squared of a wife and a husband, and being Muslim. 
same result holds for the number of births over pervious five years in column (4). In terms of magnitude, an increase of one birth measured by fecundity increases the husband's hours of work by 2.4 percent, or 0.9 hours per week, whereas an increase of one birth measured by number of births is associated with 6.0 percent, or 2.3 hours per week in rural area.

The separate estimation of female or male labour supply may induce a bias due to a selection in the marriage market. For example, there may be a negative or positive sorting in terms of preference for work (such as career ambitions). If this is the case, then the unobserved level of ambition will bias the effect of fecundity through its correlation with observable characteristics in both the wife and husband's labour supply equation. To the extent that our measure of fertility is exogenous and that the fecundity is likely to be revealed after matching, the bias is likely to be minimal. Nevertheless, we estimate Equation 5 and Equation 8 jointly with the following restriction imposed on the error terms in order to test for this possibility.

$$
\left(\begin{array}{c}
\epsilon_{M} \\
\epsilon_{F}
\end{array}\right) \mid W_{M}, W_{F}, X, \mu, \varepsilon \sim N\left(\left(\begin{array}{l}
0 \\
0
\end{array}\right)\left(\begin{array}{cc}
\sigma_{M}^{2} & \sigma_{M F} \\
\sigma_{M F} & \sigma_{F}^{2}
\end{array}\right)\right)
$$

The results, presented in Appendix C, shows that there exists a positive sorting in terms of preference for work, but that the estimates on the effect of fecundity are robust to those matching mechanism.

\section{$5 \quad$ Explaining Rural/Urban Differentials}

The change of male labour supply in response to fertility suggests that the specialization within a household is more prevalent in rural areas than in urban areas. There are several possible explanations. In this section we make simple tests for the range of explanations available. The first possibility is that working hours may be more flexible in rural communities than in urban ones due to the structure of the local economy. Whereas agriculture is the dominant industry in rural areas, 
manufacturing and service industry tends to be dominant in urban areas. If the choice of working hours is more flexible for farmers than for employees in manufacturing or in the service industry, this may explain the urban/rural differences. ${ }^{7}$ We test this possibility by including the industry characteristic of the husband's occupation and its interaction with measures of fecundity in the male labour supply equation. Obviously, we do not claim causal effects of occupational status since the choice of occupation itself is clearly endogenous with respect to the working hours. Rather we investigate whether the difference in the effect of fecundity on male labour supply in rural and urban areas in Indonesia can be explained by the correlation between occupational choice and rural/urban dummy variables. The same point applies to the other explanations discussed below. The categories for occupational status are professional (baseline category), service, agriculture and manufacturing. The results are presented in Table 6. Column (1) of Table 6 presents the basic specification identical to column (2) in Table 5, where the p-value for the same effect of permanent component of fecundity in rural and urban areas is 8.6 percent. Column (2) of Table 6 suggests that people in service and manufacturing industries work more than professionals but that the rural/urban differential persists even when occupational choice considered. When the interaction between occupation and fecundity is included as in column (3) of Table 6, the coefficient on the permanent component of fecundity in rural area becomes insignificant, but its magnitude remains similar to that in column (1). Although the p-value for the same coefficients on fecundity (mu) in rural and urban areas is 13.6 percent, the magnitude of the coefficients suggests that the occupationspecific characteristics are not the main source for the rural/urban differentials in the male labour supply response to fecundity.

Second, within the framework of bargaining models, husbands may exhibit stronger power in

\footnotetext{
${ }^{7}$ There are other characteristics that might be correlated with occupations. For example, people with higher level of ambition may choose to work as a professional rather than being employed in agriculture or manufacturing.
} 
rural areas due to traditional social norms that are reflected in stronger gender roles. If men's marginal utility from consumption goods is higher than that of women, the difference in the male labour supply may be a reflection of bargaining power. The most common measures of household bargaining power, or the distribution factor in a collective setting, are the difference in earnings between husband and wife and the share of the wife's income (Browning and Chiappori 1998). Since reliable information on earnings or the share of income of members in a household is not available for the IFLS, we use the difference in education as a reasonable proxy for earning differentials between husband and wife. ${ }^{8}$ Including the average and the difference in schooling of a couple instead of the schooling of each member, the rural/urban differential still remains significant. Including the interaction of the difference in education and measures of fecundity does not alter the finding either. ${ }^{9}$ As an additional measure of the distribution factor, we control for whether the couple lives with the husband or wife's parents. If the couple live with the parents of the husband, then this may increase his bargaining power. Likewise, the wife's bargaining power might be stronger if the couple lives with her parents. ${ }^{10}$ However, columns (4) and (5) in Table 6 show no substantial change in the coefficient on the fecundity, mu, once these two variables and their interaction with fecundity are controlled for. In so far living with parents reflects more conservative gender roles, bargaining

\footnotetext{
${ }^{8}$ We do not aim to test a collective model of household behaviour versus a unitary model, which requires a demand system with at least five goods (Browning and Chiappori 1998). Rather we explore whether the variation in the male labour supply response to fertility can be explained by some measures of distribution factor in a conditional demand framework.

${ }^{9}$ The results of this specification (which is different from the basic one reported in Table 5), are not reported but available from the authors on request.

${ }^{10}$ One related observation is Kim (2005), who finds that living with parents-in-law is associated with a woman's shorter second birth interval and that living with own parents is associated with a longer second birth interval. If a longer birth interval is desirable for a woman's health, therefore, in her interest, this finding suggests that the presence of parents-in-law or own parents may be correlated with bargaining power between a husband and a wife.
} 
power does not seem to explain the rural/urban differentials in male labour supply discussed above.

A third factor is that the cost of childcare may be higher in urban areas than in rural areas. Facing the high cost of childcare relative to wage, husbands may decrease their leisure or labour supply to share the duty of childcare or other household work. The presence of other household members might have an effect on labour supply, in that they (perhaps a female relative or a grand mother) might be available to care for young children. In this sense, the presence of other women in the household reflects the value (or the cost) of childcare. The fact that households in rural Indonesia are often characterized by extended families whereas nuclear families are the norm in urban areas plays a significant role on the perceived cost of childcare. Whereas external childcare (i.e. formal childcare) is more expensive in urban areas, it is also more available. In contrast external childcare might be cheaper in rural areas, but less available. In any case, the presence of other family members available for child caring might explain the rural and urban differentials in terms of labour supply. When the number of women older than 14 years in a household is included as a regressor as in columns (6) of Table 6, there is no significant change in the coefficients on fecundity, mu, in rural and urban areas. When the number of women and its interaction with fecundity, mu, is controlled for in column (7), the coefficient on fecundity in rural area decreases by 40 percent in magnitude compared to that in column (6), and becomes insignificant. Nevertheless, the p-value for the same coefficients on fecundity in rural and urban areas is still the same level as column (1). Consequently, the number of women does not explain the rural/urban differentials decisively. An alternative measure of cost of childcare is the level of household expenditure on children's education. Descriptive statistics suggests that urban household spends more on children's education than rural households. Including educational spending as a regressor (columns (8)) gives no significant change in the coefficients on fecundity, mu. Column (9), where the interaction between the positive educational expenditure and fecundity is additionally included, shows that 


\section{Table 6: Male Labour Supply and Heterogeneity (Regression Model)}

\begin{tabular}{|c|c|c|c|c|c|c|c|c|c|}
\hline $\begin{array}{l}\text { Community fixed effects } \\
\text { Dependent variable: log of male weekly hours o }\end{array}$ & $\begin{array}{c}(1) \\
\text { YES } \\
\text { working i }\end{array}$ & $\begin{array}{c}(2) \\
\text { YES } \\
n 1993\end{array}$ & $\begin{array}{c}(3) \\
\text { YES }\end{array}$ & $\begin{array}{l}(4) \\
\text { YES }\end{array}$ & $\begin{array}{l}(5) \\
\text { YES }\end{array}$ & $\begin{array}{l}(6) \\
\text { YES }\end{array}$ & $\begin{array}{l}(7) \\
\text { YES }\end{array}$ & $\begin{array}{c}(8) \\
\text { YES }\end{array}$ & $\begin{array}{l}(9) \\
\text { YES }\end{array}$ \\
\hline$\widehat{\mu}^{*} \mathrm{URBAN}\left(\gamma_{5}\right)$ & $\begin{array}{c}-0.0104 \\
(0.65)\end{array}$ & $\begin{array}{c}-0.0094 \\
(0.59)\end{array}$ & $\begin{array}{c}-0.0047 \\
(0.11)\end{array}$ & $\begin{array}{c}-0.0109 \\
(0.67)\end{array}$ & $\begin{array}{c}-0.0128 \\
(0.78)\end{array}$ & $\begin{array}{c}-0.0107 \\
(0.66)\end{array}$ & $\begin{array}{c}-0.0215 \\
(0.81)\end{array}$ & $\begin{array}{c}-0.0102 \\
(0.63)\end{array}$ & $\begin{array}{l}0.0275 \\
(1.20)\end{array}$ \\
\hline$\widehat{\varepsilon}^{*} \operatorname{URBAN}\left(\gamma_{6}\right)$ & $\begin{array}{l}-0.0074 \\
(0.42)\end{array}$ & $\begin{array}{l}-0.0048 \\
(0.27)\end{array}$ & $\begin{array}{l}-0.0206 \\
(0.46)\end{array}$ & $\begin{array}{c}-0.0066 \\
(0.37)\end{array}$ & $\begin{array}{c}-0.0047 \\
(0.25)\end{array}$ & $\begin{array}{c}-0.0074 \\
(0.41)\end{array}$ & $\begin{array}{l}0.0222 \\
(0.76)\end{array}$ & $\begin{array}{c}-0.0074 \\
(0.42)\end{array}$ & $\begin{array}{l}-0.0053 \\
(0.21)\end{array}$ \\
\hline$\widehat{\mu}^{*} \operatorname{RURAL}\left(\gamma_{7}\right)$ & $\begin{array}{l}0.0229 \\
(2.09)\end{array}$ & $\begin{array}{l}0.0217 \\
(2.00)\end{array}$ & $\begin{array}{l}0.0270 \\
(0.65)\end{array}$ & $\begin{array}{l}0.0229 \\
(2.10)\end{array}$ & $\begin{array}{l}0.0218 \\
(1.82)\end{array}$ & $\begin{array}{l}0.0228 \\
(2.09)\end{array}$ & $\begin{array}{l}0.0127 \\
(0.58)\end{array}$ & $\begin{array}{l}0.0232 \\
(2.12)\end{array}$ & $\begin{array}{l}0.0540 \\
(3.25)\end{array}$ \\
\hline$\widehat{\varepsilon} *$ RURAL $\left(\gamma_{8}\right)$ & $\begin{array}{c}-0.0197 \\
(1.65)\end{array}$ & $\begin{array}{c}-0.0174 \\
(1.47)\end{array}$ & $\begin{array}{c}-0.0406 \\
(0.90)\end{array}$ & $\begin{array}{c}-0.0199 \\
(1.67)\end{array}$ & $\begin{array}{c}-0.0177 \\
(1.36)\end{array}$ & $\begin{array}{c}-0.0199 \\
(1.67)\end{array}$ & $\begin{array}{l}0.0066 \\
(0.28)\end{array}$ & $\begin{array}{c}-0.0198 \\
(1.66)\end{array}$ & $\begin{array}{c}-0.0129 \\
(0.69)\end{array}$ \\
\hline Husband's job: service & & $\begin{array}{l}0.1991 \\
(3.73)\end{array}$ & $\begin{array}{l}0.1758 \\
(2.71)\end{array}$ & & & & & & \\
\hline Husband's job: agriculture & & $\begin{array}{c}-0.0629 \\
(1.09)\end{array}$ & $\begin{array}{c}-0.0928 \\
(1.35)\end{array}$ & & & & & & \\
\hline Husband's job: manufacture & & $\begin{array}{l}0.1069 \\
(1.96)\end{array}$ & $\begin{array}{l}0.1044 \\
(1.61)\end{array}$ & & & & & & \\
\hline$\widehat{\mu}^{*}$ Husband's job: service & & & $\begin{array}{c}-0.0252 \\
(0.57)\end{array}$ & & & & & & \\
\hline$\widehat{\mu}^{*}$ Husband's job: agriculture & & & $\begin{array}{c}-0.0114 \\
(0.26)\end{array}$ & & & & & & \\
\hline$\widehat{\mu}^{*}$ Husband's job: manufacture & & & $\begin{array}{l}0.0136 \\
(0.32)\end{array}$ & & & & & & \\
\hline$\widehat{\varepsilon}^{*}$ Husband's job:service & & & $\begin{array}{l}0.0333 \\
(0.70)\end{array}$ & & & & & & \\
\hline$\widehat{\varepsilon}^{*}$ Husband's job: agriculture & & & $\begin{array}{l}0.0364 \\
(0.77)\end{array}$ & & & & & & \\
\hline$\widehat{\varepsilon}^{*}$ Husband's job: manufacture & & & $\begin{array}{c}-0.0013 \\
(0.03)\end{array}$ & & & & & & \\
\hline Living with wife's parents & & & & $\begin{array}{c}-0.0730 \\
(1.53)\end{array}$ & $\begin{array}{c}-0.0334 \\
(0.58)\end{array}$ & & & & \\
\hline Living with husband's parents & & & & $\begin{array}{l}-0.0096 \\
(0.18)\end{array}$ & $\begin{array}{c}-0.0480 \\
(0.77)\end{array}$ & & & & \\
\hline$\widehat{\mu}^{*}$ Living with wife's parents & & & & & $\begin{array}{l}0.0093 \\
(0.28)\end{array}$ & & & & \\
\hline$\widehat{\mu}^{*}$ Living with husband's parents & & & & & $\begin{array}{l}0.0349 \\
(0.97)\end{array}$ & & & & \\
\hline$\widehat{\varepsilon}^{*}$ Living with wife's parents & & & & & $\begin{array}{c}-0.0426 \\
(1.18)\end{array}$ & & & & \\
\hline$\widehat{\varepsilon}^{*}$ Living with husband's parents & & & & & $\begin{array}{l}0.0374 \\
(1.00)\end{array}$ & & & & \\
\hline No. of women older than 14 years & & & & & & $\begin{array}{c}-0.0169 \\
(1.00)\end{array}$ & $\begin{array}{c}-0.0035 \\
(0.18)\end{array}$ & & \\
\hline$\widehat{\mu}^{*}$ No. of women older than 14 years & & & & & & & $\begin{array}{l}0.0072 \\
(0.52)\end{array}$ & & \\
\hline$\widehat{\varepsilon}^{*}$ No.of women older than 14 years & & & & & & & $\begin{array}{l}-0.0198 \\
(1.29)\end{array}$ & & \\
\hline Index for positive educational expenditure & & & & & & & & $\begin{array}{l}0.0286 \\
(0.86)\end{array}$ & $\begin{array}{l}0.0474 \\
(1.23)\end{array}$ \\
\hline$\widehat{\mu}^{*}$ Index for positive educational expenditure & & & & & & & & & $\begin{array}{c}-0.0456 \\
(2.35)\end{array}$ \\
\hline$\widehat{\varepsilon}^{*}$ Index for positive educational expenditure & & & & & & & & & $\begin{array}{c}-0.0047 \\
(0.22)\end{array}$ \\
\hline Constant & $\begin{array}{l}7.4863 \\
(23.62)\end{array}$ & $\begin{array}{l}7.3928 \\
(23.13)\end{array}$ & $\begin{array}{l}7.4042 \\
(23.06)\end{array}$ & $\begin{array}{l}7.4824 \\
(23.61)\end{array}$ & $\begin{array}{l}7.4821 \\
(23.56)\end{array}$ & $\begin{array}{l}7.4951 \\
(23.64)\end{array}$ & $\begin{array}{l}7.4435 \\
(23.29)\end{array}$ & $\begin{array}{l}7.5526 \\
(23.14)\end{array}$ & $\begin{array}{l}7.5385 \\
(23.08)\end{array}$ \\
\hline No. of Observations & 3,210 & 3,210 & 3,210 & 3,210 & 3,210 & 3,210 & 3,210 & 3,210 & 3,210 \\
\hline No. of Communities & 311 & 311 & 311 & 311 & 311 & 311 & 311 & 311 & 311 \\
\hline $\begin{array}{l}\mathrm{R} \text { squared } \\
p \text {-values for }\end{array}$ & 0.01 & 0.03 & 0.03 & 0.01 & 0.01 & 0.01 & 0.01 & 0.01 & 0.01 \\
\hline$H_{0}: \gamma_{5}=\gamma_{7}$ & 0.086 & 0.107 & 0.136 & 0.082 & 0.079 & 0.084 & 0.080 & 0.086 & $\overline{0.181}$ \\
\hline$H_{0}: \gamma_{6}=\gamma_{8}$ & 0.563 & 0.548 & 0.383 & 0.531 & 0.543 & 0.555 & 0.464 & 0.559 & 0.723 \\
\hline
\end{tabular}

Notes: Absolute value of asymptotic $t$-ratios are in parentheses. The data used are the 1993 Indonesian Family Life Survey. All columns include community fixed effects. Measure of Fecundity is adjusted so that one unit of fecundity is equivalent to an increase by one expected birth over 5 years. Other regressors include age, age squared, schooling and schooling squared of a wife and a husband and being Muslim. 
the difference between the coefficients on the permanent component of fecundity, mu, in rural and urban areas becomes smaller. The magnitude of the difference $\left(\left|\gamma_{5}-\gamma_{6}\right|\right)$ is less than 0.270 in column (9), where it is larger than 0.310 in all other columns. The p-value for the same coefficients on fecundity in rural and urban areas is 18.1 percent suggesting that those coefficients are not likely to be different from each other. The coefficients on the permanent component of fecundity $\left(\gamma_{5}\right.$ and $\left.\gamma_{6}\right)$ and the interaction of fecundity and the index for the positive educational expenditure suggest that husbands increase labour supply in response to an exogenous increase in fertility only when there is no educational expenditure. Hence, the cost of raising a child seems to be important in explaining the rural/urban differentials in labour supply in response to changes in fertility. ${ }^{11}$

\section{Conclusion}

This paper focuses on the consequence of fertility on both male and female labour market participation. The theoretical consideration encompasses both a unitary and a collective model of family labour supply and fertility. Although further assumptions need to be made concerning the functional form of utility in order to derive predictions of the model, one empirical question is whether an exogenous increase in fertility will reinforce or lessen the degree of household division of labour.

Taking the unobserved natural variation of fertility as a measure of fecundity, the empirical analysis suggests that Indonesian couples respond differently in rural and urban areas. In urban

\footnotetext{
${ }^{11}$ There exist other possible explanations. Given that consumption good and child good are complementary, the level of income may explain the difference. If households in rural areas have on average a lower income than those in urban areas, they will have a higher marginal utility from consumption good, and therefore, will increase male labour supply with a higher level of fertility. Including an index for having a non-labour income and its interaction with fecundity does not change the magnitude and significance of the coefficients on fecundity. However, the result is not reported here because of the reduction of the sample size due the limited availability of the information on non-labour income in the IFLS.
} 
areas, women decrease hours of work by 1.1 hours per week in response to an exogenous increase of one birth over the previous five years, whereas men do not respond significantly. In rural areas, in contrast, the same increase of births leads to a reduction in women's hours of work by 1.1 hours per week and a significant increase in men's working hours by 0.9 hours per week. In all the cases, it is confirmed that using the number of children as a measure of fertility significantly exaggerates the magnitude of the consequence of fertility in terms of family labour supply, which is consistent with Rosenzweig and Schultz (1985). The results still hold when the correlation of female and male preference through matching in the marriage market is controlled for.

Our analysis suggests that the different response of male labour supply for an increase in fertility in rural and urban areas in Indonesia are mainly due to the differences in the cost of childcare rather than the characteristics of occupation or the bargaining power. The finding that men as well as women do respond to the trade-off between the cost of childcare and the value of their time extends the scope of the literature on childbearing and labour market outcomes, and provides a piece of evidence against the usual assumption that a husband's income is exogenous with respect to a wife's labour supply or the choice of childbearing even in the context of developing countries. 


\section{References}

[1] Aassve, A., S. Burgess, M. Dickson and C. Propper (2005), "Modelling Poverty by not Modelling Poverty: An Application of a Simultaneous Hazards Approach to the UK", Department of Economics, University of Bristol, mimeo.

[2] Angrist, J. D. and W. N. Evans (1996), "Children and Their Parents' Labour Supply: Evidence from Exogenous Variation in Family Size", National Bureau of Economic Research (Cambridge, MA, U.S.A.) Working Paper No. 5778.

[3] Angrist, J. D. and W. N. Evans (1998), “Children and Their Parents' Labour Supply: Evidence from Exogenous Variation in Family Size", The American Economic Review, 88(3), pp. 450-77.

[4] Becker, G. (1985), "Human Capital, Efforts, and the Sexual Division of Labour", Journal of Labour Economics, 3(1), Part 2, January, pp. S33-58.

[5] Becker, G. and H. G. Lewis (1973), "On the Interaction between the Quantity and Quality of Children", Journal of Political Economy, 81(2), Part 2, Mar-Apr, pp. S279-88.

[6] Behrman, J., A. Foster, M. Rosenzweig and P. Vahsishtha (1999), "Women's Schooling, Home Teaching, and Economic Growth", Journal of Political Economy, 107(4), August, pp. 682-714.

[7] Blundell, R. and T. Macurdy (1999), "Labour Supply: A Review of Alternative Approaches," in Handbook of Labour Economics, O. Ashenfelter and D. Card, eds., Elsevier Science, pp. 1559-695.

[8] Browning, M. (1992), "Children and Household Economic Behavior", Journal of Economic Literature, Vol. 30, no. 3, September, pp. 1434-75.

[9] Browning, M. and P. A. Chiappori (1998), "Efficient Intra-Household Allocations: A General Characterization and Empirical Tests", Econometrica, Vol. 66, No. 6, pp. 1241-78. 
[10] Ermisch, J. F. (2003), An Economic Analysis of the Family. Princeton, NJ: Princeton University Press.

[11] Heckman, J. J. (1979), "Sample Selection Bias as a Specification Error", Econometrica, 47, January, pp. 153-62.

[12] Hotz, V. J., J. Klerman, and R. Willis (1997), "The Economics of Fertility in Developed Countries," in Handbook of Population and Family Economics, M. Rosenzweig and O. Stark, eds., Elsevier Science, pp. 276-348.

[13] Millimet, D. L. (2000). "The Impact of Children on Wages, Job Tenure, and The Division of Household Labour", The Economic Journal 110(March), pp. C139-57.

[14] Lam, D. and S. Duryea (1999), "Effects of Schooling on Fertility, Labour Supply, and Investments in Children, with Evidence from Brazil", Journal of Human Resources, Vol.34, No.1, pp. 160-92.

[15] Lundberg, S. and E. Rose (2000), "Parenthood and the earnings of married men and women", Labour Economics 7, pp. 689- 710.

[16] Lundberg, S. and E. Rose (2002), "The Effects of Sons and Daughters on Mens' Labour Supply and Wages", The Review of Economics and Statistics 84(2), pp. 251- 68.

[17] Kim, J. (2005), "Women's Education in the Fertility Transition: The Reversal of the Relationship Between Women's Education and Birth Spacing in Indonesia", VID Working Papers 05/2005. Vienna: Vienna Institute of Demography.

[18] Pagan, A. (1984) "Econometric Issues in the Analysis of Regressions with Generated Regressors", International Economic Review, Vol. 25, No. 1, pp. 221-47. 
[19] Rosenzweig, M. (1990), "Population growth and human capital investments: theory and evidence", Journal of Political Economy 98(5), pp. S12-70.

[20] Rosenzweig, M. and T. P. Schultz (1985), "The Demand for and Supply of Births: Fertility and its Life Cycle Consequences", American Economic Review 75(5), pp. 992-1015.

[21] Rosenzweig, M. and K. Wolpin (1980), "Testing the Quantity-Quality Fertility Model: The Use of Twins as a Natural Experiment", Econometrica 48(1), pp. 227-40.

[22] Schultz, T. P. (1997), "Demand for Children in Low Income Countries," in Handbook of Population and Family Economics, M. Rosenzweig and O. Stark, eds., Elsevier Science, pp. $349-430$. 


\section{Appendix}

A First Stage Estimation in the Two Stage Least Squares Esti-

mation

Table 7: First Stage Ordinary Least Squares Estimation in Table 2

\begin{tabular}{|c|c|c|c|c|c|c|}
\hline Dependent Variables & $\begin{array}{l}\text { (1) } \\
\text { No. of births } \\
\text { prior to } 1988 \\
\end{array}$ & $\begin{array}{c}(2) \\
\text { Pills }\end{array}$ & $\begin{array}{c}(3) \\
\text { IUD }\end{array}$ & $\begin{array}{c}(4) \\
\text { Injection, Implant, } \\
\text { Diaphragm, Condom }\end{array}$ & $\begin{array}{c}5) \\
\text { Sterilization }\end{array}$ & $\begin{array}{c}6) \\
\text { Ineffective } \\
\text { methods }\end{array}$ \\
\hline Age in 1988 & $\begin{array}{l}0.1715 \\
(7.52)\end{array}$ & $\begin{array}{l}0.0193 \\
(5.37)\end{array}$ & $\begin{array}{l}0.0166 \\
(4.73)\end{array}$ & $\begin{array}{l}0.0199 \\
(5.71)\end{array}$ & $\begin{array}{c}-0.0004 \\
(0.19)\end{array}$ & $\begin{array}{l}0.0024 \\
(1.19)\end{array}$ \\
\hline Age in 1988 sq. & $\begin{array}{l}0.0004 \\
(0.96)\end{array}$ & $\begin{array}{c}-0.0003 \\
(5.48)\end{array}$ & $\begin{array}{c}-0.0002 \\
(4.01)\end{array}$ & $\begin{array}{c}-0.0004 \\
(6.67)\end{array}$ & $\begin{array}{l}0.0001 \\
(1.38)\end{array}$ & $\begin{array}{l}0.0000 \\
(0.60)\end{array}$ \\
\hline Schooling & $\begin{array}{l}-0.0927 \\
(10.01)\end{array}$ & $\begin{array}{l}0.0011 \\
(0.73)\end{array}$ & $\begin{array}{l}0.0045 \\
(3.16)\end{array}$ & $\begin{array}{c}-0.0005 \\
(0.37)\end{array}$ & $\begin{array}{l}0.0004 \\
(0.45)\end{array}$ & $\begin{array}{l}0.0019 \\
(2.28)\end{array}$ \\
\hline Husband's Schooling & $\begin{array}{c}-0.0016 \\
(0.18)\end{array}$ & $\begin{array}{c}-0.0017 \\
(1.30)\end{array}$ & $\begin{array}{l}0.0031 \\
(2.37)\end{array}$ & $\begin{array}{l}0.0022 \\
(1.70)\end{array}$ & $\begin{array}{l}0.0003 \\
(0.35)\end{array}$ & $\begin{array}{l}0.0019 \\
(2.51)\end{array}$ \\
\hline Muslim & $\begin{array}{l}0.4529 \\
(3.65)\end{array}$ & $\begin{array}{l}0.0406 \\
(2.08)\end{array}$ & $\begin{array}{c}-0.0079 \\
(0.41)\end{array}$ & $\begin{array}{l}0.0544 \\
(2.87)\end{array}$ & $\begin{array}{c}-0.0487 \\
(3.87)\end{array}$ & $\begin{array}{c}-0.0274 \\
(2.51)\end{array}$ \\
\hline Number of Women of age above nine & $\begin{array}{c}0.5285 \\
(18.32)\end{array}$ & $\begin{array}{l}0.0073 \\
(1.61)\end{array}$ & $\begin{array}{l}0.0111 \\
(2.50)\end{array}$ & $\begin{array}{c}-0.0006 \\
(0.13)\end{array}$ & $\begin{array}{l}0.0110 \\
(3.76)\end{array}$ & $\begin{array}{c}-0.0015 \\
(0.60)\end{array}$ \\
\hline Living w/ Parents & $\begin{array}{c}-0.7205 \\
(7.72)\end{array}$ & $\begin{array}{c}-0.0200 \\
(1.36)\end{array}$ & $\begin{array}{c}-0.0187 \\
(1.30)\end{array}$ & $\begin{array}{c}-0.0220 \\
(1.55)\end{array}$ & $\begin{array}{c}-0.0185 \\
(1.96)\end{array}$ & $\begin{array}{c}-0.0078 \\
(0.95)\end{array}$ \\
\hline Living w/ Parent-in-laws & $\begin{array}{c}-0.5913 \\
(5.34)\end{array}$ & $\begin{array}{c}-0.0004 \\
(0.02)\end{array}$ & $\begin{array}{c}-0.0187 \\
(1.10)\end{array}$ & $\begin{array}{c}0.0167 \\
(0.99)\end{array}$ & $\begin{array}{l}0.0015 \\
(0.14)\end{array}$ & $\begin{array}{l}0.0042 \\
(0.43)\end{array}$ \\
\hline Constant & $\begin{array}{c}-3.0653 \\
(8.81)\end{array}$ & $\begin{array}{c}-0.1813 \\
(3.31)\end{array}$ & $\begin{array}{c}-0.2111 \\
(3.94)\end{array}$ & $\begin{array}{c}-0.1583 \\
(2.98)\end{array}$ & $\begin{array}{l}0.0186 \\
(0.53)\end{array}$ & $\begin{array}{c}-0.0142 \\
(0.46)\end{array}$ \\
\hline No. of Observation & 4,548 & 4,548 & 4,548 & 4,548 & 4,548 & 4,548 \\
\hline R-squared & 0.55 & 0.01 & 0.02 & 0.02 & 0.03 & 0.01 \\
\hline
\end{tabular}

Notes: Absolute value of asymptotic $t$-ratios are in parentheses. The data used are the 1993 Indonesian Family Life Survey. The number of observations exceed that in the summary statistics because this sample includes all the observations with non-missing values for the variables used in this table. Community fixed effects are removed in all the columns. 


\section{B Probit Estimation and the Importance of Controlling for Com- munity Fixed-Effects}

We analyse women's labour market participation using a Probit model as an alternative specification. The dependent variable is the index for working in 1993. The independent variables include a couple's basic characteristics and measures of fertility. The results are presented in Table 8. In models (1) and (2) fecundity are included as regressors, whereas models (3) and (4) use live births as regressors. Columns (2) and (4) control for rural/urban differentials, whereas models (1) and (3) do not. Models (5) to (8) are similar to those of (1) - (4) apart from the control for community fixed effects. The basic specification in Column (1) shows that the female labour market participation peaks at the age of 50. The effect of own education also exhibits a non-linear pattern. For less than five years of schooling, women with more education work less, while women with more education work more for more than five years of schooling. The impact of husband's schooling on wife's labour supply is also highly non-linear, indicating that for more than three years of husband's schooling, wife's labour supply decreases, which can be seen as an income effect. Women in Muslim households tend to work less, but this effect seems to be a reflection of the correlation between religion and the characteristics of communities given that its significance disappears when community fixed-effects are controlled for. Neither the permanent nor the random component of fecundity has a significant impact on women's labour market participation. In the basic specification we also see that fecundity has no significant impact on labour supply. Although this changes when fecundity is interacted with the urban/rural variables, and also changes when fertility is measured by live births, models (5) to (8) show the importance of controlling for the variation in prices and infrastructure at the level of local economy. The general sign of the coefficients are the same, but the magnitude and significance are different. Column (5) shows that the permanent component of 
fecundity $(\mathrm{m})$ has a negative and significant impact on female labour market participation. At the mean value of all the variables, a marginal increase of fecundity lowers the probability of female working by 1.8 percent. On the other hand, according to column (7) the marginal effect of the number of live births over the previous five years is negative 4.8 percent. The comparison between column (5) and (7) suggests that using the number of live births as a measure of fertility exaggerates the consequence of fertility in female labour supply. The p-values shown at the bottom of column (6) and (8) of Table 8 suggest that the negative effect of fecundity on women's labour supply is not significantly different across rural and urban areas although the estimates for rural areas are larger in magnitudes than those for urban areas. Hence, women tend to work less in response to an increase in fecundity both in rural and urban areas in Indonesia. 
Table 8: Effects of Fecundity on Female Labour Market Participation (Probit Model)

\begin{tabular}{|c|c|c|c|c|c|c|c|c|}
\hline $\begin{array}{l}\text { Community fixed effects } \\
\text { Dependent variable: index for working in } 1993\end{array}$ & $(1)$ & $(2)$ & (3) & $(4)$ & $\begin{array}{l}(5) \\
\text { YES }\end{array}$ & $\begin{array}{l}(6) \\
\text { YES }\end{array}$ & $\begin{array}{l}(7) \\
\text { YES }\end{array}$ & $\begin{array}{l}(8) \\
\text { YES }\end{array}$ \\
\hline Wife's age & $\begin{array}{l}0.1214 \\
(3.51)\end{array}$ & $\begin{array}{l}0.1291 \\
(3.72)\end{array}$ & $\begin{array}{l}0.1170 \\
(3.39)\end{array}$ & $\begin{array}{l}0.1266 \\
(3.65)\end{array}$ & $\begin{array}{l}0.1407 \\
(3.40)\end{array}$ & $\begin{array}{l}0.1393 \\
(3.36)\end{array}$ & $\begin{array}{l}0.1294 \\
(3.13)\end{array}$ & $\begin{array}{l}0.1272 \\
(3.07)\end{array}$ \\
\hline Wife's age squared & $\begin{array}{l}-0.0014 \\
(3.00)\end{array}$ & $\begin{array}{c}-0.0015 \\
(3.23)\end{array}$ & $\begin{array}{c}-0.0014 \\
(3.01)\end{array}$ & $\begin{array}{l}-0.0015 \\
(3.23)\end{array}$ & $\begin{array}{c}-0.0016 \\
(2.88)\end{array}$ & $\begin{array}{c}-0.0016 \\
(2.85)\end{array}$ & $\begin{array}{l}-0.0016 \\
(2.78)\end{array}$ & $\begin{array}{c}-0.0016 \\
(2.72)\end{array}$ \\
\hline Wife's schooling & $\begin{array}{l}-0.0829 \\
(4.53)\end{array}$ & $\begin{array}{c}-0.0816 \\
(4.46)\end{array}$ & $\begin{array}{c}-0.0852 \\
(4.64)\end{array}$ & $\begin{array}{c}-0.0768 \\
(4.16)\end{array}$ & $\begin{array}{c}-0.0864 \\
(3.82)\end{array}$ & $\begin{array}{c}-0.0865 \\
(3.83)\end{array}$ & $\begin{array}{c}-0.0912 \\
(4.03)\end{array}$ & $\begin{array}{c}-0.0910 \\
(4.01)\end{array}$ \\
\hline Wife's schooling squared & $\begin{array}{l}0.0085 \\
(5.90)\end{array}$ & $\begin{array}{l}0.0086 \\
(5.93)\end{array}$ & $\begin{array}{l}0.0087 \\
(6.03)\end{array}$ & $\begin{array}{l}0.0087 \\
(5.97)\end{array}$ & $\begin{array}{l}0.0104 \\
(5.92)\end{array}$ & $\begin{array}{l}0.0104 \\
(5.93)\end{array}$ & $\begin{array}{l}0.0107 \\
(6.10)\end{array}$ & $\begin{array}{l}0.0107 \\
(6.06)\end{array}$ \\
\hline Husband's age & $\begin{array}{c}-0.0131 \\
(0.56)\end{array}$ & $\begin{array}{c}-0.0165 \\
(0.70)\end{array}$ & $\begin{array}{c}-0.0166 \\
(0.70)\end{array}$ & $\begin{array}{c}-0.0186 \\
(0.79)\end{array}$ & $\begin{array}{c}-0.0043 \\
(0.16)\end{array}$ & $\begin{array}{c}-0.0024 \\
(0.09)\end{array}$ & $\begin{array}{c}-0.0048 \\
(0.17)\end{array}$ & $\begin{array}{c}-0.0046 \\
(0.17)\end{array}$ \\
\hline Husband's age squared & $\begin{array}{l}0.0002 \\
(0.62)\end{array}$ & $\begin{array}{l}0.0002 \\
(0.76)\end{array}$ & $\begin{array}{l}0.0002 \\
(0.75)\end{array}$ & $\begin{array}{l}0.0002 \\
(0.81)\end{array}$ & $\begin{array}{c}0.0001 \\
(0.21)\end{array}$ & $\begin{array}{l}0.0000 \\
(0.14)\end{array}$ & $\begin{array}{c}0.0001 \\
(0.22)\end{array}$ & $\begin{array}{l}0.0001 \\
(0.21)\end{array}$ \\
\hline Husband's schooling & $\begin{array}{c}0.0294 \\
(1.62)\end{array}$ & $\begin{array}{l}0.0349 \\
(1.92)\end{array}$ & $\begin{array}{l}0.0291 \\
(1.60)\end{array}$ & $\begin{array}{l}0.0419 \\
(2.28)\end{array}$ & $\begin{array}{l}0.0324 \\
(1.45)\end{array}$ & $\begin{array}{l}0.0324 \\
(1.44)\end{array}$ & $\begin{array}{l}0.0310 \\
(1.39)\end{array}$ & $\begin{array}{l}0.0310 \\
(1.38)\end{array}$ \\
\hline Husband's schooling squared & $\begin{array}{c}-0.0046 \\
(3.57)\end{array}$ & $\begin{array}{c}-0.0048 \\
(3.71)\end{array}$ & $\begin{array}{c}-0.0045 \\
(3.54)\end{array}$ & $\begin{array}{c}-0.0048 \\
(3.74)\end{array}$ & $\begin{array}{c}-0.0042 \\
(2.69)\end{array}$ & $\begin{array}{c}-0.0042 \\
(2.71)\end{array}$ & $\begin{array}{c}-0.0041 \\
(2.63)\end{array}$ & $\begin{array}{c}-0.0041 \\
(2.63)\end{array}$ \\
\hline Muslim & $\begin{array}{c}-0.2398 \\
(3.60)\end{array}$ & $\begin{array}{c}-0.2304 \\
(3.45)\end{array}$ & $\begin{array}{c}-0.2467 \\
(3.69)\end{array}$ & $\begin{array}{c}-0.2189 \\
(3.25)\end{array}$ & $\begin{array}{c}-0.1947 \\
(1.54)\end{array}$ & $\begin{array}{c}-0.1973 \\
(1.56)\end{array}$ & $\begin{array}{c}-0.1964 \\
(1.56)\end{array}$ & $\begin{array}{c}-0.1938 \\
(1.54)\end{array}$ \\
\hline$\widehat{\mu}$ (permanent component of fecundity) & $\begin{array}{c}-0.0133 \\
(0.81)\end{array}$ & & & & $\begin{array}{c}-0.0451 \\
(2.15)\end{array}$ & & & \\
\hline$\widehat{\varepsilon}$ (random component of fecundity) & $\begin{array}{l}0.0106 \\
(0.57)\end{array}$ & & & & $\begin{array}{l}0.0238 \\
(1.02)\end{array}$ & & & \\
\hline No. of live births between 1989 and 1992 & & & $\begin{array}{c}-0.0562 \\
(1.69)\end{array}$ & & & & $\begin{array}{c}-0.1192 \\
(2.83)\end{array}$ & \\
\hline No. of live births prior to 1989 & & & $\begin{array}{c}0.0109 \\
(0.89)\end{array}$ & & & & $\begin{array}{c}0.0055 \\
(0.36)\end{array}$ & \\
\hline$\widehat{\mu} * \operatorname{URBAN}\left(\beta_{5}\right)$ & & $\begin{array}{c}0.0331 \\
(1.17)\end{array}$ & & & & $\begin{array}{c}-0.0242 \\
(0.71)\end{array}$ & & \\
\hline$\widehat{\varepsilon} * \operatorname{URBAN}\left(\beta_{6}\right)$ & & $\begin{array}{c}-0.0845 \\
(2.91)\end{array}$ & & & & $\begin{array}{l}0.0459 \\
(1.20)\end{array}$ & & \\
\hline$\widehat{\mu} * \operatorname{RURAL}\left(\beta_{7}\right)$ & & $\begin{array}{c}-0.0360 \\
(1.78)\end{array}$ & & & & $\begin{array}{c}-0.0601 \\
(2.27)\end{array}$ & & \\
\hline$\widehat{\varepsilon} *$ RURAL $\left(\beta_{8}\right)$ & & $\begin{array}{c}0.0571 \\
(2.61)\end{array}$ & & & & $\begin{array}{l}0.0096 \\
(0.33)\end{array}$ & & \\
\hline No. of live births between 1989 and $1992 *$ URBAN $\left(\beta_{9}\right)$ & & & & $\begin{array}{c}-0.1732 \\
(3.67)\end{array}$ & & & & $\begin{array}{c}-0.1051 \\
(1.73)\end{array}$ \\
\hline No. of live births prior to $1989 *$ URBAN $\left(\beta_{10}\right)$ & & & & $\begin{array}{c}-0.0316 \\
(2.26)\end{array}$ & & & & $\begin{array}{c}-0.0018 \\
(0.09)\end{array}$ \\
\hline No. of live births between 1989 and $1992 *$ RURAL $\left(\beta_{11}\right)$ & & & & $\begin{array}{c}-0.0018 \\
(0.05)\end{array}$ & & & & $\begin{array}{c}-0.1318 \\
(2.34)\end{array}$ \\
\hline No. of live births prior to $1989 *$ RURAL $\left(\beta_{12}\right)$ & & & & $\begin{array}{l}0.0445 \\
(3.26)\end{array}$ & & & & $\begin{array}{l}0.0119 \\
(0.62)\end{array}$ \\
\hline Constant & $\begin{array}{c}-1.7206 \\
(3.07)\end{array}$ & $\begin{array}{c}-1.7986 \\
(3.20)\end{array}$ & $\begin{array}{c}-1.4760 \\
(2.58)\end{array}$ & $\begin{array}{c}-1.7253 \\
(2.99)\end{array}$ & $\begin{array}{c}-2.8941 \\
(3.59)\end{array}$ & $\begin{array}{c}-2.8717 \\
(3.56)\end{array}$ & $\begin{array}{c}-2.4674 \\
(3.02)\end{array}$ & $\begin{array}{c}-2.4466 \\
(2.99)\end{array}$ \\
\hline No. of Observations & 3,287 & 3,287 & 3,287 & 3,287 & 3,059 & 3,059 & 3,059 & 3,059 \\
\hline $\begin{array}{l}\text { No. of Communities } \\
p \text {-values for }\end{array}$ & & & & & 284 & 284 & 284 & 284 \\
\hline $\begin{array}{l}H_{0}: \beta_{5}=\beta_{7} \\
H_{0}: \beta_{6}=\beta_{8}\end{array}$ & & $\begin{array}{l}0.045 \\
0.000\end{array}$ & & & & $\begin{array}{l}0.402 \\
0.442\end{array}$ & & \\
\hline$H_{0}: \beta_{9}=\beta_{11}$ & & & & 0.002 & & & & 0.743 \\
\hline$H_{0}: \beta_{10}=\beta_{12}$ & & & & 0.000 & & & & 0.574 \\
\hline
\end{tabular}

Notes: Absolute value of asymptotic t-ratios are in parentheses. The data used are the 1993 Indonesian Family Life Survey. The specifications in columns (5) to (8) include community fixed effects, where the observations belonging to a group with no variation in outcome are dropped. Measure of Fecundity is adjusted so that one unit of fecundity is equivalent to an increase by one expected birth over 5 years. 


\section{Joint Estimation of Male and Female Labour Supply}

\section{Table 9: Joint Estimation of Male and Female Labour Supply (Maximum Likelihood}

Estimation)

\begin{tabular}{|c|c|c|c|c|c|c|}
\hline \multirow{3}{*}{$\begin{array}{l}\text { Community fixed effects } \\
\text { Dependent Variable: log wage of } \\
\text { Wife's age }\end{array}$} & \multicolumn{2}{|c|}{$\begin{array}{c}\text { Estimation (1) } \\
\text { YES }\end{array}$} & \multicolumn{2}{|c|}{$\begin{array}{c}\text { Estimation (2) } \\
\text { YES }\end{array}$} & \multicolumn{2}{|c|}{$\begin{array}{c}\text { Estimation (3) } \\
\text { YES }\end{array}$} \\
\hline & Wife & Husband & Wife & Husband & Wife & Husband \\
\hline & $\begin{array}{c}0.3264 \\
(3.56)\end{array}$ & $\begin{array}{c}-0.0308 \\
(1.62)\end{array}$ & $\begin{array}{l}0.3256 \\
(3.55)\end{array}$ & $\begin{array}{c}-0.0309 \\
(1.63)\end{array}$ & $\begin{array}{l}0.3166 \\
(3.47)\end{array}$ & $\begin{array}{c}-0.0290 \\
(1.53)\end{array}$ \\
\hline Wife's age squared & $\begin{array}{c}-0.0038 \\
(3.05)\end{array}$ & $\begin{array}{c}0.0004 \\
(1.35)\end{array}$ & $\begin{array}{c}-0.0038 \\
(3.04)\end{array}$ & $\begin{array}{l}0.0004 \\
(1.38)\end{array}$ & $\begin{array}{c}-0.0038 \\
(3.02)\end{array}$ & $\begin{array}{l}0.0004 \\
(1.33)\end{array}$ \\
\hline Wife's schooling & $\begin{array}{l}0.0662 \\
(2.92)\end{array}$ & $\begin{array}{c}-0.0046 \\
(0.98)\end{array}$ & $\begin{array}{l}0.0666 \\
(2.94)\end{array}$ & $\begin{array}{c}-0.0046 \\
(0.96)\end{array}$ & $\begin{array}{l}0.0633 \\
(2.78)\end{array}$ & $\begin{array}{c}-0.0042 \\
(0.88)\end{array}$ \\
\hline Husband's age & $\begin{array}{c}-0.0222 \\
(0.36)\end{array}$ & $\begin{array}{l}0.0300 \\
(2.53)\end{array}$ & $\begin{array}{c}-0.0189 \\
(0.31)\end{array}$ & $\begin{array}{l}0.0297 \\
(2.50)\end{array}$ & $\begin{array}{c}-0.0198 \\
(0.32)\end{array}$ & $\begin{array}{c}0.0297 \\
(2.46)\end{array}$ \\
\hline Husband's age squared & $\begin{array}{l}0.0003 \\
(0.41)\end{array}$ & $\begin{array}{c}-0.0003 \\
(2.75)\end{array}$ & $\begin{array}{l}0.0002 \\
(0.36)\end{array}$ & $\begin{array}{c}-0.0003 \\
(2.73)\end{array}$ & $\begin{array}{l}0.0003 \\
(0.37)\end{array}$ & $\begin{array}{c}-0.0003 \\
(2.67)\end{array}$ \\
\hline Husband's schooling & $\begin{array}{c}-0.0312 \\
(1.56)\end{array}$ & $\begin{array}{c}-0.0015 \\
(0.34)\end{array}$ & $\begin{array}{c}-0.0316 \\
(1.58)\end{array}$ & $\begin{array}{c}-0.0013 \\
(0.30)\end{array}$ & $\begin{array}{c}-0.0310 \\
(1.55)\end{array}$ & $\begin{array}{c}-0.0016 \\
(0.38)\end{array}$ \\
\hline Muslim & $\begin{array}{c}-0.4466 \\
(1.58)\end{array}$ & $\begin{array}{c}-0.0527 \\
(0.81)\end{array}$ & $\begin{array}{c}-0.4537 \\
(1.61)\end{array}$ & $\begin{array}{c}-0.0541 \\
(0.83)\end{array}$ & $\begin{array}{c}-0.4407 \\
(1.56)\end{array}$ & $\begin{array}{c}-0.0537 \\
(0.82)\end{array}$ \\
\hline$\widehat{\mu}$ (permanent component of fecundity) & $\begin{array}{c}-0.0645 \\
(1.46)\end{array}$ & $\begin{array}{l}0.0107 \\
(1.19)\end{array}$ & & & & \\
\hline$\widehat{\varepsilon}$ (random component of fecundity) & $\begin{array}{l}0.0460 \\
(0.94)\end{array}$ & $\begin{array}{c}-0.0158 \\
(1.65)\end{array}$ & & & & \\
\hline$\widehat{\mu} * \mathrm{URBAN}$ & & & $\begin{array}{c}-0.0593 \\
(0.77)\end{array}$ & $\begin{array}{c}-0.0114 \\
(0.69)\end{array}$ & & \\
\hline$\widehat{\varepsilon} *$ URBAN & & & $\begin{array}{l}0.1232 \\
(1.41)\end{array}$ & $\begin{array}{c}-0.0058 \\
(0.34)\end{array}$ & & \\
\hline$\widehat{\mu} *$ RURAL & & & $\begin{array}{c}-0.0730 \\
(1.36)\end{array}$ & $\begin{array}{l}0.0212 \\
(2.06)\end{array}$ & & \\
\hline$\widehat{\varepsilon} *$ RURAL & & & $\begin{array}{l}0.0067 \\
(0.11)\end{array}$ & $\begin{array}{c}-0.0186 \\
(1.66)\end{array}$ & & \\
\hline No. of live births between 1989 and 1992 & & & & & $\begin{array}{c}-0.1887 \\
(2.08)\end{array}$ & $\begin{array}{l}0.0287 \\
(1.47)\end{array}$ \\
\hline No. of live births prior to 1989 & & & & & $\begin{array}{c}-0.0173 \\
(0.51)\end{array}$ & $\begin{array}{l}0.0013 \\
(0.19)\end{array}$ \\
\hline Constant & $\begin{array}{c}0.7208 \\
(12.15)\end{array}$ & $\begin{array}{c}3.5022 \\
(225.21)\end{array}$ & $\begin{array}{l}0.7205 \\
(12.16)\end{array}$ & $\begin{array}{l}3.5023 \\
(225.51)\end{array}$ & $\begin{array}{c}0.7212 \\
(12.16)\end{array}$ & $\begin{array}{c}3.5022 \\
(225.61)\end{array}$ \\
\hline$\widehat{\sigma_{F}}$ & $\begin{array}{l}2.8925 \\
(20.05)\end{array}$ & & $\begin{array}{l}2.8899 \\
(20.07)\end{array}$ & & $\begin{array}{l}2.8909 \\
(20.04)\end{array}$ & \\
\hline$\widehat{\sigma_{M}}$ & & $\begin{array}{l}0.6425 \\
(92.83)\end{array}$ & & $\begin{array}{l}0.6422 \\
(92.36)\end{array}$ & & $\begin{array}{l}0.6426 \\
(92.68)\end{array}$ \\
\hline$\widehat{\sigma_{M, F}}$ & & $\begin{array}{l}0.0296 \\
(1.52)\end{array}$ & & $\begin{array}{l}0.0299 \\
(1.53)\end{array}$ & & $\begin{array}{l}0.0302 \\
(1.55)\end{array}$ \\
\hline Log Likelihood & -875 & 8.95 & -875 & 6.36 & -875 & 8.01 \\
\hline No. of Observations & 3,2 & 287 & 3,2 & 287 & & 287 \\
\hline No. of Communities & 31 & 11 & 3. & 11 & & 11 \\
\hline
\end{tabular}

Notes: Absolute values of asymptotic t-ratios are in parentheses. The data used are the 1993 Indonesian Family Life Survey. The community fixed effects are removed by the auxiliary estimation. Measure of Fecundity is adjusted so that one unit of fecundity is equivalent to an increase by one expected birth over 5 years. 